\title{
Maria Cecília Guirado. Relatos do descobrimento do Brasil as primeiras reportagens
}

Francisco Silva Noelli

Laboratório de Arqueologia, Etno-História e Etnologia,

Universidade Estadual de M aringá - UEM

Lisboa: Instituto Piaget, 2001, 305p.

0 diário de Pero Lopes de Sousa, escrito entre 1530 e 1532, éuma fonte de grande importância para a história da fase inicial de exploração do Brasil meridional e da foz do rio da Prata, sendo o segundo documento oficial português conhecido a ser escrito em terras brasileiras. Foi descoberto na Biblioteca Real do Paço da Ajuda, em 1839, depois de estar "escondido" por cerca de trezentos anos. 0 diário teve dez edições em língua portuguesa, entre 1839 e 1989, mas apenas três foram realizadas a partir da transcrição direta do manuscrito encontrado na Ajuda, a saber: 1) 1839, por Francisco Adolfo de Varnhagen; 2) 1956, por Jaime Cortesão; 3) 1968, por Jorge M orais-Barbosa. Todavia, o códice não éo diário original, mas uma "cópia incompleta e pouco cuidada do que teriam sido as anotações de Pero Lopes", escrita com letra do século XVI.

A 11ª edição do diário, publicada em Portugal no ano de 2001, por Maria Cecília Guirado, éa mel hor de todas, por tratar-se da primeira edição crítica do manuscrito da Ajuda e por apresentar ao leitor, especialista ou leigo, uma série de informações relevantes sobre o contexto da viagem eda redação do diário de Pero Lopes. Esta avaliação resultou de uma cuidadosa e erudita abordagem interdisciplinar, muito contemporânea, entre jornalismo, filologia, semiótica ehistória, maiso suporteda pal eografia, com objetivo de "dar um tratamento jornalístico-semiótico ... sem esquecer-se de retirar destes textos quadros significativos sobre a evolução das relações de alteridade, do enfrentamento civilizacional entre indígenas e portugueses". Além do diário, Guiarado apresenta duas análises curtas, mas importantes abordagens jornalísticas da carta de Pero Vaz deCaminha, escrita em 1500, eda H istória da Província de Santa Cruz, publicada em Lisboa por Pero de M agal hães Gandavo, em 1576.

0 enfoque central da obra é a questão da comunicação no período do descobrimento, sobre os objetivos dos cronistas ao elaborar suas narrativas e relatórios de viagem. Da competente análise de Guirado, vimos surgir um 
contexto em que os navegadores e os encarregados de tomar posse das novas terras estavam muito preparados em relação aos conhecimentos da época. Vemos exemplos de matemáticos portugueses, como Pedro Nunes, que em 1537 estava preocupado em aliar teoria e prática, escapando do empirismo utilitário: "manifesto é que estes descobrimentos de costas, ilhas e terras firmes não se fizeram indo a acertar, mas partiam os nossos mareantes muito ensinados e providos de instrumentos e regras de astrologia e geometria, que são as cousas de que os cosmógrafos hão-de andar apercebidos".

A edição crítica do diário de Pero Lopes é, sem dúvida, a grande contribuição de Guirado às pesquisas e aos pesquisadores dos descobrimentos portugueses. Antecedendo a transcrição paleográfica, vemos uma descrição detaIhada do códice da Ajuda, a história completa das dez edições anteriores e a explicitação pormenorizada dos critérios usados na transcrição pal eográfica, uma verdadeira aula para orientar iniciantes e profissionais em tarefas dessa natureza. A transcrição é acompanhada de várias notas de rodapé, com esclarecimentos pertinentes, e dos símbolos utilizados nos códigos de transcrição da topografia do manuscrito. Da mesma maneira procede na explicação detal hada dos fundamentos teóricos e dos procedimentos práticos utilizados para elaborar os critérios da edição crítica, incluindo regras para "regularização da epiderme gráfica" e aspectos para fixação da ortografia, em outra aula construída com erudição efluidez literária.

O texto crítico do códice vem acompanhado de notas de rodapé com explicações sobre detalhes da redação e, com muita propriedade, do cotejo in loco com as variantes de texto encontradas nas edições anteriores. A autora explica que, ao fazer tal procedimento, as anotações "poderão ajudar o leitor a compreender o processo desta edição crítica".

O texto crítico é seguido por um glossário de "termos de marinharia", do "léxico comum caído em desuso e outros termos", dos personagens citados e dos topônimos, baseado em atestações buscadas no mais completo conjunto deobras sobre os referidos assuntos. A inclusão desse aparato é de grande valia, poisé um complemento fundamental para a compreensão exata e completa do diário.

Se a edição crítica realizada por M aria Cecília Guirado passará a figurar como a melhor publicação do diário, é preciso lembrar que a segunda edição de Eugênio de Castro (1940) é a mais completa análise e interpretação, talvez definitiva, sobre o itinerário descrito no diário de Pero Lopes de Sousa. Ambas as obras, em razão do alto nível alcançado pelos seus autores, devem ser consideradas como consulta obrigatória para aqueles que pesquisam sobre as primeiras décadas da presença portuguesa na América do Sul.

Resenha recebida em 05/2003. Aprovada em 10/2005 